\title{
A hydrogen dependent geochemical analogue of primordial carbon and energy metabolism
}

Martina Preiner ${ }^{1,8}$, Kensuke Igarashi ${ }^{2,8}$, Kamila B. Muchowska ${ }^{3,8}$, Mingquan $\mathrm{Yu}^{4,8}$, Sreejith J. Varma $^{5}$, Karl Kleinermanns ${ }^{6}$, Masaru K. Nobu ${ }^{7}$, Yoichi Kamagata ${ }^{7}$, Harun Tüysüz ${ }^{4 *}$, Joseph $\operatorname{Moran}^{3 *}$, William F. Martin ${ }^{1 *}$

${ }^{8}$ These authors contributed equally: Martina Preiner, Kensuke Igarashi, Kamila B. Muchowska, Mingquan Yu

* e-mail: bill@hhu.de, moran@unistra.fr, tueysuez@mpi-muelheim.mpg.de

${ }^{1}$ Institute of Molecular Evolution, Heinrich-Heine-University, 40225 Düsseldorf, Germany

${ }^{2}$ Bioproduction Research Institute, National Institute of Advanced Industrial Science and Technology (AIST), 2-17-2-1 Tsukisamu-Higashi, Toyohira-ku, Sapporo, Hokkaido 0628517, Japan

${ }^{3}$ Université de Strasbourg, CNRS, ISIS UMR 7006, F-67000 Strasbourg, France

${ }^{4}$ Max-Planck-Institut für Kohlenforschung, Kaiser-Wilhelm-Platz 1, 45470 Mülheim an der Ruhr, Germany

${ }^{5}$ Charité - Universitätsmedizin Berlin, Laboratory "Biochemistry and System Biology of the Metabolism", Charitéplatz 1, 10117 Berlin, Germany

${ }^{6}$ Institute for Physical Chemistry, Heinrich-Heine-University, 40225 Düsseldorf, Germany

${ }^{7}$ Bioproduction Research Institute, National Institute of Advanced Industrial Science and Technology (AIST), 1-1-1 Higashi, Tsukuba, Ibaraki 305-8566, Japan

Keywords: Origin of life, serpentinization, hydrothermal vents, early Earth, abiotic carbon fixation, protometabolism, geochemical catalysis. 


\section{Abstract:}

Hydrogen gas, $\mathrm{H}_{2}$, is generated in alkaline hydrothermal vents from reactions of iron containing minerals with water during a geological process called serpentinization. It has been a source of electrons and energy since there was liquid water on the early Earth, and it fuelled early anaerobic ecosystems in the Earth's crust ${ }^{1-3} . \mathrm{H}_{2}$ is the electron donor for the most ancient route of biological $\mathrm{CO}_{2}$ fixation, the acetyl-CoA (or Wood-Ljungdahl) pathway, which unlike any other autotrophic pathway simultaneously supplies three key requirements for life: reduced carbon in the form of acetyl groups, electrons in the form of reduced ferredoxin, and ion gradients for energy conservation in the form of $\mathrm{ATP}^{4,5}$. The pathway is linear, not cyclic, it releases energy rather than requiring energy input, its enzymes are replete with primordial metal cofactors ${ }^{6,7}$, it traces to the last universal common ancestor ${ }^{8}$ and abiotic, geochemical organic syntheses resembling segments of the pathway occur in hydrothermal vents today ${ }^{9,10}$. Laboratory simulations of the acetyl-CoA pathway's reactions include the nonenzymatic synthesis of thioesters from $\mathrm{CO}$ and methylsulfide ${ }^{11}$, the synthesis of acetate ${ }^{12}$ and pyruvate ${ }^{13}$ from $\mathrm{CO}_{2}$ using native iron or external electrochemical potentials ${ }^{14}$ as the electron source. However, a full abiotic analogue of the acetyl-CoA pathway from $\mathrm{H}_{2}$ and $\mathrm{CO}_{2}$ as it occurs in life has not been reported to date. Here we show that three hydrothermal minerals - awaruite $\left(\mathrm{Ni}_{3} \mathrm{Fe}\right)$, magnetite $\left(\mathrm{Fe}_{3} \mathrm{O}_{4}\right)$ and greigite $\left(\mathrm{Fe}_{3} \mathrm{~S}_{4}\right)$ - catalyse the fixation of $\mathrm{CO}_{2}$ with $\mathrm{H}_{2}$ at $100{ }^{\circ} \mathrm{C}$ under alkaline aqueous conditions. The product spectrum includes formate $(100 \mathrm{mM})$, acetate $(100 \mu \mathrm{M})$, pyruvate $(10 \mu \mathrm{M})$, methanol $(100 \mu \mathrm{M})$, and methane. With these simple catalysts, the overall exergonic reaction of the acetyl-CoA pathway is facile, shedding light on both the geochemical origin of microbial metabolism and on the nature of abiotic formate and methane synthesis in modern hydrothermal vents.

Organic synthesis in hydrothermal vents is relevant to life's origin because the reactions involve sustained energy release founded in the disequilibrium between $\mathrm{CO}_{2}$ and the vast amounts of molecular hydrogen, $\mathrm{H}_{2}$, generated in the Earth's crust during serpentinization ${ }^{1,2,9,10,15-19}$. Enzymatic versions of those abiotic reactions occur in core energy metabolism in acetogens and methanogens ${ }^{4-7}$, ancient anaerobic autotrophs that live from $\mathrm{H}_{2}$ and $\mathrm{CO}_{2}$ via the acetyl-CoA pathway and that still inhabit the crust today ${ }^{7}$. Though the enzymes that catalyse the microbial reactions are well investigated ${ }^{4-7}$, the catalysts promoting the abiotic reactions in vents today, and that might have been instrumental at life's origin, are not fully understood ${ }^{9}$. To probe the mechanisms of hydrothermal metabolic reactions 
emulating ancient pathways, we investigated three iron minerals that naturally occur in hydrothermal vents: greigite $\left(\mathrm{Fe}_{3} \mathrm{~S}_{4}\right)$, magnetite $\left(\mathrm{Fe}_{3} \mathrm{O}_{4}\right)$, and the nickel iron alloy awaruite $\left(\mathrm{Ni}_{3} \mathrm{Fe}\right)$. Although very different in structure and composition (Fig. 1), all three are geochemically synthesized in hydrothermal vents from pre-existing divalent iron and nickel minerals during serpentinization ${ }^{2,16,20}$. X-ray diffraction (XRD) of colloidal $\mathrm{Fe}_{3} \mathrm{~S}_{4}$ and $\mathrm{Ni}_{3} \mathrm{Fe}$ nanoparticles (for details of preparation, see Methods) as well as commercial $\mathrm{Fe}_{3} \mathrm{O}_{4}$ reveal their characteristic pattern (Fig. 1).
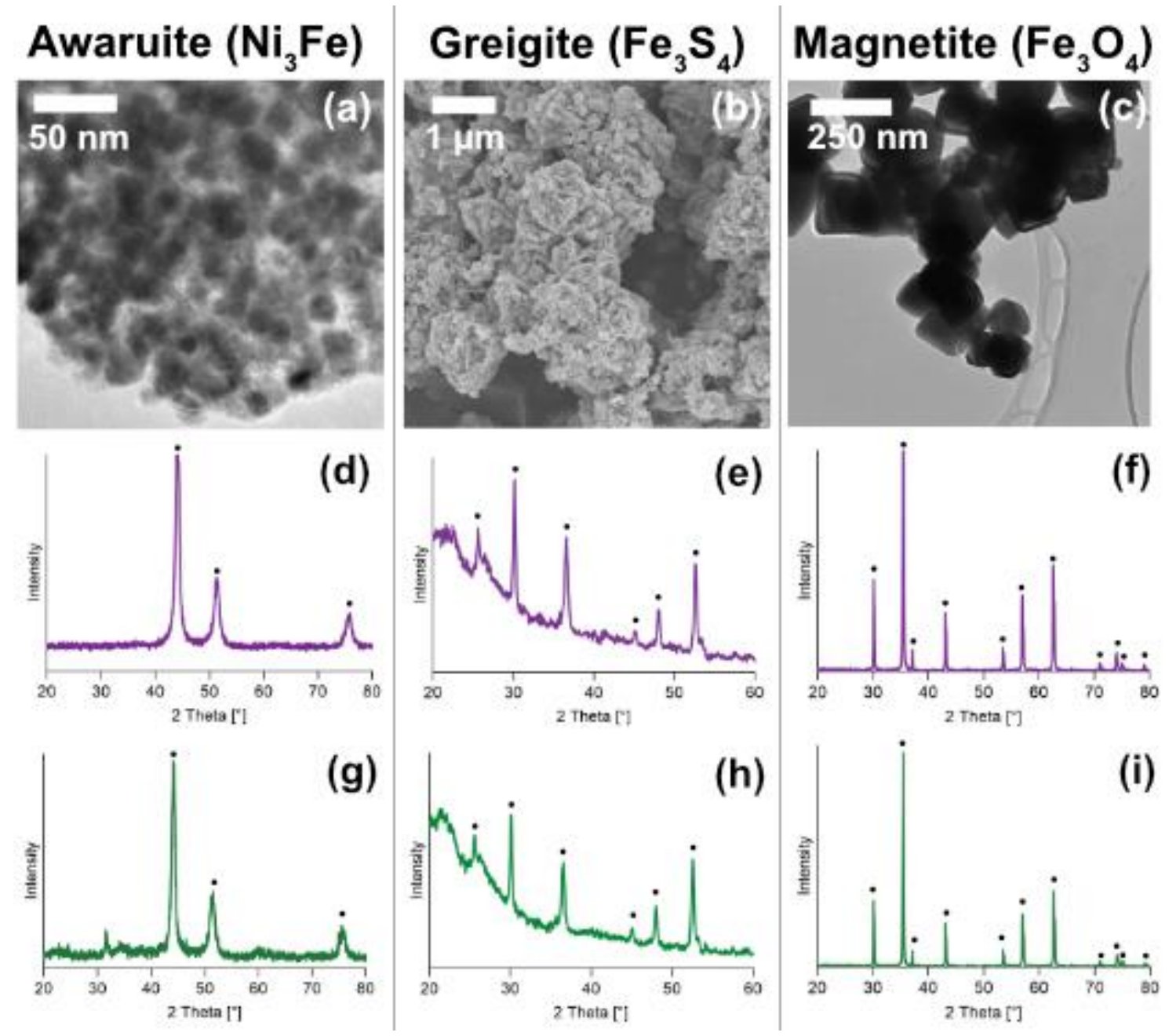

Figure 1: Characterization of greigite $\left(\mathrm{Fe}_{3} \mathrm{~S}_{4}\right)$, magnetite $\left(\mathrm{Fe}_{3} \mathrm{O}_{4}\right)$ and awaruite $\left(\mathrm{Ni}_{3} \mathrm{Fe}\right)$ catalysts. The three powders are different in structure and composition (a, b, c), greigite and awaruite are freshly synthesized, magnetite is commercially obtained. Comparison the XRDs of the minerals before the reaction $(\mathrm{d}, \mathrm{e}, \mathrm{f})$ and after the experiments under following conditions: $\mathrm{Fe}_{3} \mathrm{O}_{4}$ (h) and $\mathrm{Ni}_{3} \mathrm{Fe}$ (i) for 
$16 \mathrm{~h}$ under alkaline conditions (potassium hydroxide added). $\mathrm{Fe}_{3} \mathrm{~S}_{4}$

(g), for $24 \mathrm{~h}$ at $\mathrm{pH} 6.5$, stabilized by a phosphate buffer.

Iron sulfide minerals are formed under conditions of high $\mathrm{H}_{2} \mathrm{~S}$ activity ${ }^{16}$ and have long been regarded as ancient catalysts ${ }^{11,17,21}$, but the key initial reaction between the inorganic and the organic world, $\mathrm{CO}_{2}$ fixation, has not been reported using iron sulfur catalysts under biologically relevant conditions ${ }^{14}$. We found that under mild hydrothermal conditions ( 2 bar, $100{ }^{\circ} \mathrm{C}$ ) formate and acetate synthesis from $\mathrm{H}_{2}$ and $\mathrm{CO}_{2}$ occurs readily under nearly neutral and alkaline conditions in the presence of the hydrothermal mineral $\mathrm{Fe}_{3} \mathrm{~S}_{4}$ (Fig. 2a). While only formate was detected at $20^{\circ} \mathrm{C}$, acetate also accumulates at $60{ }^{\circ} \mathrm{C}$ (Fig. 2b). At 100 bar, $\mathrm{Fe}_{3} \mathrm{~S}_{4}$ catalyses the synthesis of formate and methane from $\mathrm{H}_{2}$ and $\mathrm{CO}_{2}$, but not from $\mathrm{CO}$ (Supplementary Fig. S8). Formate and methane are the main products of organic synthesis observed in the effluent of modern serpentinizing hydrothermal systems ${ }^{19}$. Greigite is similar in structure to the iron sulfur clusters of many modern enzymes ${ }^{17}$. 


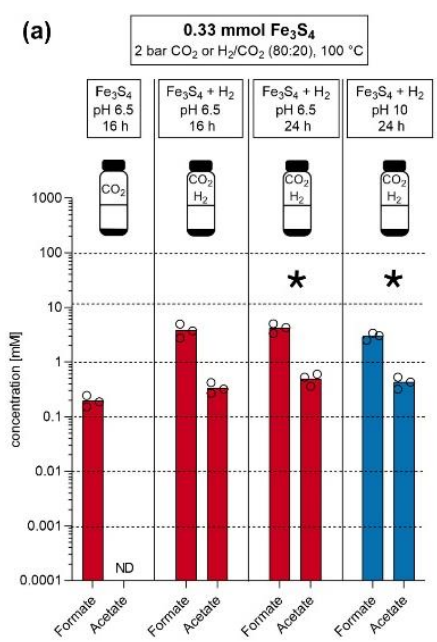

(c)

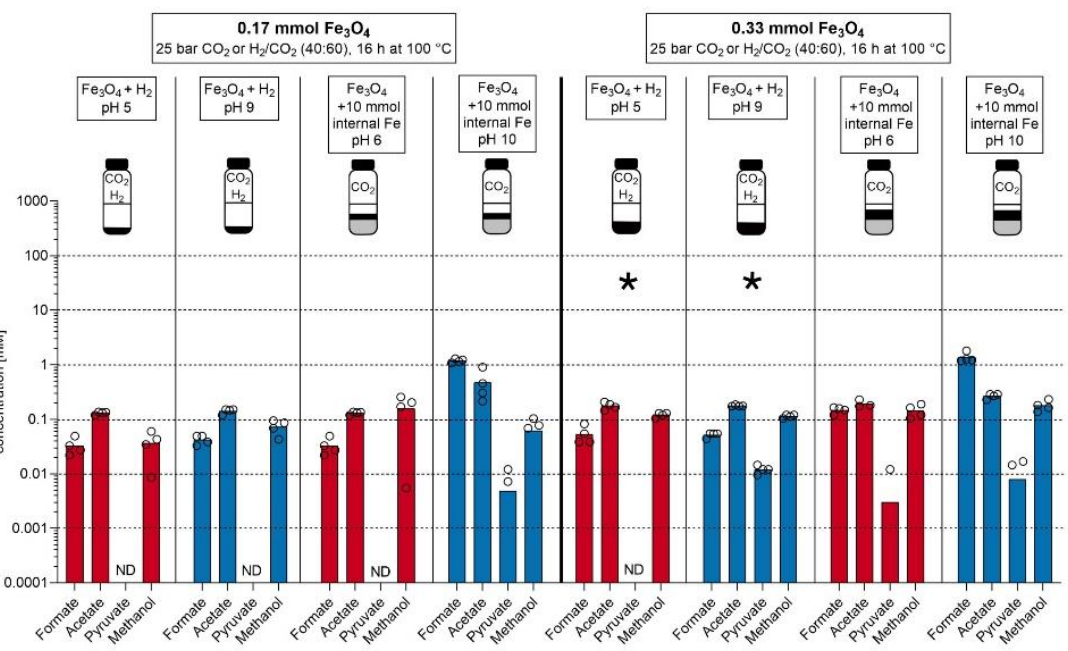

(b)

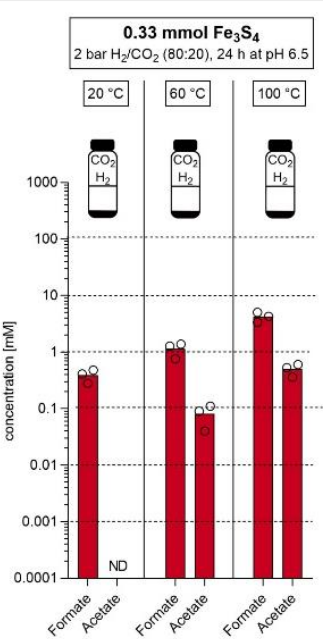

(d)

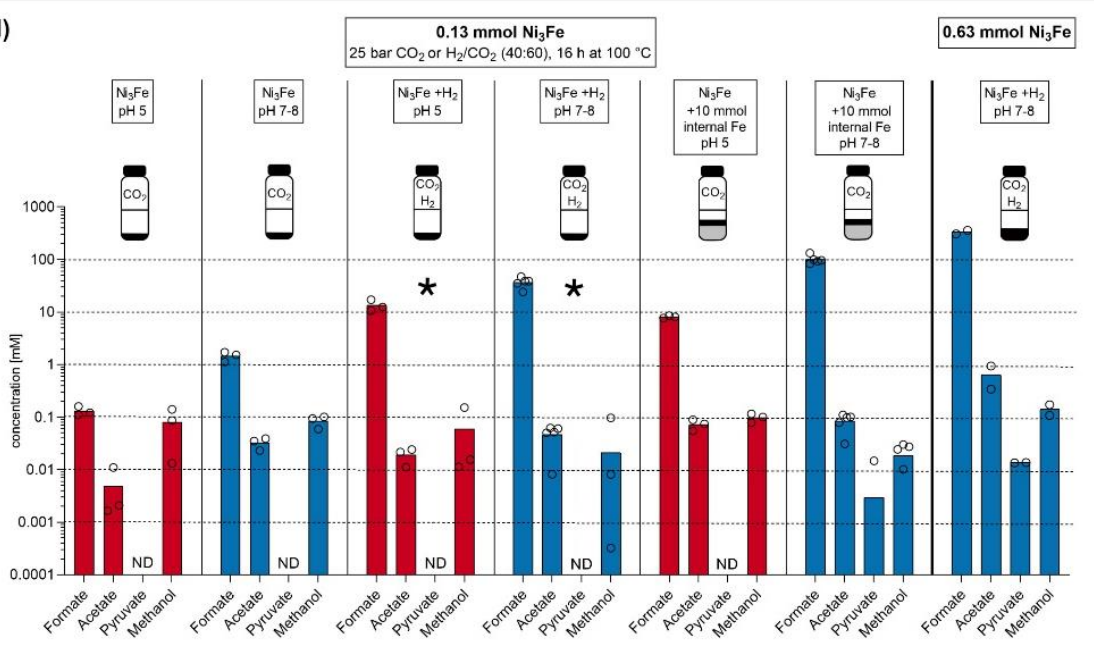

Figure 2: Fixation of $\mathrm{CO}_{2}$ with $\mathrm{H}_{2}$, catalysed by greigite $(\mathrm{a}, \mathrm{b})$, magnetite (c) and awaruite (d). All reactions were performed in water (1 $\mathrm{mL}$ for magnetite and awaruite, $3 \mathrm{~mL}$ for greigite). Flasks in each panel summarize the reaction parameters: hydrothermal minerals are depicted in black, additional iron powder in grey. Catalyst amounts are normalised by the number of moles of metal atoms per mole of mineral compound, $0.33 \mathrm{mmol}$ of greigite $\left(\mathrm{Fe}_{3} \mathrm{~S}_{4}\right)$ or magnetite $\left(\mathrm{Fe}_{3} \mathrm{O}_{4}\right)$, as well as $0.25 \mathrm{mmol}$ of awaruite are equivalent to $1 \mathrm{mmol}$ of metal atoms each $(0.13 \mathrm{mmol}$ awaruite are equivalent to $0.50 \mathrm{mmol}$ of metal atoms). Individual experiments were performed under either $\mathrm{CO}_{2}$ atmosphere, $\mathrm{H}_{2} / \mathrm{CO}_{2}$ atmosphere, or $\mathrm{CO}_{2}$ atmosphere with $\mathrm{Fe}$ powder as electron $/ \mathrm{H}_{2}$ source. Red bars: $\mathrm{pH}<7$, Blue bars: $\mathrm{pH}>7$. ND: not detected (no product was formed or product concentration was below the detection limit). Circles correspond to the values of individual experiments. Values of 0 are not shown by the logarithmic 
scale. Asterisks indicate experiments for which the Gibbs free energy was calculated in Tab. 1. Concentration values and standard deviations of the experiments are listed in the supplementary information (Tab.1), as are control experiments (Figs. S3-S6). The influence of $\mathrm{pH}(4-10)$ and reaction time $(0-24 \mathrm{~h})$ on the reactions catalysed by greigite is shown in supplementary material (Fig. S7).

Magnetite $\left(\mathrm{Fe}_{3} \mathrm{O}_{4}\right)$, like $\mathrm{H}_{2}$, is a main end product of serpentinization, it is formed from water dependent oxidation of iron(II) silicates ${ }^{22}$. In chemical industry it is the catalyst of choice for diverse industrial processes including Haber-Bosch (fixation of $\mathrm{N}_{2}$ ) and Fischer-Tropsch hydrocarbon synthesis ${ }^{18}$. We found that magnetite, like greigite, catalyses the aqueous synthesis of formate and acetate in the range of $10 \mu \mathrm{M}$ to $1 \mathrm{mM}$ from $\mathrm{H}_{2}$ and $\mathrm{CO}_{2}$, but also methanol and pyruvate under mild (25 bar and $100{ }^{\circ} \mathrm{C}$ ) hydrothermal conditions (Fig. 2c). Pyruvate is a crucial intermediate of carbon and energy metabolism in all microbes and a main product of $\mathrm{CO}_{2}$ fixation in autotrophs that use the acetyl-CoA pathway ${ }^{4}$. It accumulates at 5-10 $\mu \mathrm{M}$ in the presence of $\mathrm{Fe}_{3} \mathrm{O}_{4}$, but only under alkaline conditions tested, using either native $\mathrm{Fe}$ or $\mathrm{H}_{2}$ as the reductant (Fig 2c).

Awaruite $\left(\mathrm{Ni}_{3} \mathrm{Fe}\right)$ is an alloy of native metals and a product of serpentinization that forms at high $\mathrm{H}_{2}$ partial pressures and low $\mathrm{H}_{2} \mathrm{~S}$ activities ${ }^{16}$. It is common in serpentinizing systems, where it is usually deposited as small grains. Its synthesis is thought to involve reduction of iron(II) and nickel(II) during phases of serpentinization in which very high $\mathrm{H}_{2}$ partial pressures are incurred ${ }^{16}$. At $100{ }^{\circ} \mathrm{C}$, awaruite catalyses the synthesis of acetate and methanol in the 10-100 $\mu \mathrm{M}$ range at $\mathrm{pH} 5-8$ whereby either the native alloy, native $\mathrm{Fe}$, or $\mathrm{H}_{2}$ function as the reductant (Fig. 2d). At alkaline $\mathrm{pH}$, with either native $\mathrm{Fe}$ or $\mathrm{H}_{2}$ as reductant, formate accumulates in the $100 \mathrm{mM}$ range and pyruvate reaches 5-10 $\mu \mathrm{M}$ (Fig. 2d). In some experiments, we detected ethanol in concentrations up to over $100 \mu \mathrm{M}$ (Fig. S10). $\mathrm{Ni}_{3} \mathrm{Fe}$ also catalyses $\mathrm{CO}_{2}$ fixation under alkaline conditions at $70{ }^{\circ} \mathrm{C}$, and even small amounts of $\mathrm{Ni}_{3} \mathrm{Fe}$ are active in thermal gradients from $100{ }^{\circ} \mathrm{C}$ to $30^{\circ} \mathrm{C}$ (Fig. S11), conditions similar to natural alkaline hydrothermal vents ${ }^{23}$. We observed trace amounts of ca. 19 ppm methane in awaruite catalysed reactions (Fig. S14 and S15), which is substantially less than an earlier report using $\mathrm{H}_{2}$ and $\mathrm{CO}_{2}$ for $1-2$ weeks at 500 bar and $200-400{ }^{\circ} \mathrm{C}$ with awaruite as the catalyst ${ }^{24}$. Our findings show that awaruite is an effective catalyst for organic synthesis overnight from $\mathrm{H}_{2}$ 
and $\mathrm{CO}_{2}$ under hydrothermal conditions that, in terms of temperature and energetics, are mild enough to permit microbial growth. Of the catalysts employed, only awaruite showed minor alteration after reaction, probably due to mild oxidation (Fig. 1g-i).

Formate accumulation catalysed by awaruite reflects the near-equilibrium interconversion of $\mathrm{H}_{2}-\mathrm{CO}_{2}$ and formate. Under physiological conditions, the reducing power of $\mathrm{H}_{2}$ is insufficient to reduce $\mathrm{CO}_{2}$, which is why microbes studied so far that reduce $\mathrm{CO}_{2}$ with electrons from $\mathrm{H}_{2}$ employ flavin-based electron bifurcation to synthesize reduced iron sulfur clusters in ferredoxin for $\mathrm{CO}_{2}$ fixation ${ }^{5,25}$. With sufficient $\mathrm{H}_{2}$ and suitable inorganic catalysts, organic cofactors are not required for $\mathrm{CO}_{2}$ fixation to form products of the acetyl-CoA pathway (Fig. 2).

Sustained synthesis of reactive organic compounds was essential at the origin of metabolism and had to be thermodynamically favourable. Equations 1-5 show the redox reactions taking place between $\mathrm{CO}_{2}$ and $\mathrm{H}_{2}$ to form formate (1), methanol (2), acetate (3), pyruvate (4), and methane (5).

$$
\begin{aligned}
\mathrm{H}_{2}+\mathrm{CO}_{2} & \rightarrow \mathrm{HCOO}^{-}+\mathrm{H}^{+} \\
3 \mathrm{H}_{2}+\mathrm{CO}_{2} & \rightarrow \mathrm{CH}_{3} \mathrm{OH}+\mathrm{H}_{2} \mathrm{O} \\
4 \mathrm{H}_{2}+2 \mathrm{CO}_{2} & \rightarrow \mathrm{CH}_{3} \mathrm{COO}^{-}+2 \mathrm{H}_{2} \mathrm{O}+\mathrm{H}^{+} \\
5 \mathrm{H}_{2}+3 \mathrm{CO}_{2} & \rightarrow \mathrm{CH}_{3}(\mathrm{CO}) \mathrm{COO}^{-}+3 \mathrm{H}_{2} \mathrm{O}+\mathrm{H}^{+} \\
4 \mathrm{H}_{2}+\mathrm{CO}_{2} & \rightarrow \mathrm{CH}_{4}+2 \mathrm{H}_{2} \mathrm{O}
\end{aligned}
$$

The changes in Gibbs free energy, $\Delta \mathrm{G}$, for six of the $\mathrm{H}_{2}$-dependent reactions performed here are given in Table 1 (detailed datasets are shown in supplementary Table S2). The synthesis of observed products is close to equilibrium or exergonic. For most compounds and conditions, product generation did not reach equilibrium, indicating kinetic inhibition of the reactions. Only $\mathrm{H}_{2}$-dependent reduction of $\mathrm{CO}_{2}$ to formate approached equilibrium in the presence of greigite or awaruite. Pyruvate and $\mathrm{CH}_{4}$ production were only detected under specific conditions despite being exergonic in nearly all treatments. For example, in treatments with $\mathrm{H}_{2}$ and magnetite/awaruite, pyruvate generation was only detected when the amount of mineral was increased (Fig. 2). $\mathrm{H}_{2}$-dependent reduction of formate to acetate (eq. 3 - eq. $1 ; 3 \mathrm{H}_{2}+\mathrm{CHOO}^{-}+\mathrm{CO}_{2} \rightarrow \mathrm{CH}_{3} \mathrm{COO}^{-}+2 \mathrm{H}_{2} \mathrm{O}$ ) consistently reached similar $\Delta \mathrm{G}$ values 
for each mineral regardless of $\mathrm{pH}$ and mineral amount (roughly $-70,-89$, and $-113 \mathrm{~kJ} \mathrm{~mol}^{-1}$ for greigite, magnetite, and awaruite respectively at $100{ }^{\circ} \mathrm{C}$ ), suggesting the possibility of similar catalytic mechanisms. All three minerals meet kinetic inhibitions for acetate synthesis $(\Delta \mathrm{G}<<0)$ providing opportunity for energetic coupling. For those reactions in which no $\mathrm{H}_{2}$ was added, only native metals were available as reductant (Supplementary Figs. S5, S9a, S12, S13), likely generating intermediate $\mathrm{H}_{2}$ from water.

Table 1: Changes in Gibbs free energy $\Delta \mathrm{G}$ for the $\mathrm{CO}_{2}$ fixation product formation in $\mathrm{kJ} \mathrm{mol}^{-1}$.

\begin{tabular}{|c|c|c|c|c|c|c|}
\hline Product & 1 & 2 & 3 & 4 & 5 & 6 \\
\hline Formate & 0.31 & -25.58 & -21.15 & -48.83 & -3.13 & -13.11 \\
\hline Methanol & -39.57 & -39.57 & -49.44 & -47.70 & -48.75 & -53.74 \\
\hline Acetate & -71.00 & -96.69 & -110.74 & -137.16 & -115.73 & -127.18 \\
\hline Pyruvate & 9.07 & -15.93 & -42.90 & -71.47 & -42.90 & -57.18 \\
\hline Methane & -152.98 & -152.98 & -187.17 & -187.17 & -187.17 & -187.17 \\
\hline
\end{tabular}

Notes: The values of $\Delta \mathrm{G}$ refer to the reactions as shown in equations 1-5. The conditions are those of reactions marked with asterisks in Fig. 2. Details of reaction conditions for columns 1-6: 1) $0.33 \mathrm{mmol}$ $\mathrm{Fe}_{3} \mathrm{~S}_{4}, 100{ }^{\circ} \mathrm{C}, 24 \mathrm{~h}, \mathrm{pH} 6.5,2$ bar $\mathrm{H}_{2} / \mathrm{CO}_{2}(80: 20)$; 2) $0.33 \mathrm{mmol}$ $\mathrm{Fe}_{3} \mathrm{~S}_{4}, 100{ }^{\circ} \mathrm{C}, 24 \mathrm{~h}, \mathrm{pH} \mathrm{10,} 2$ bar $\mathrm{H}_{2} / \mathrm{CO}_{2}(80: 20)$; 3) $0.17 \mathrm{mmol}$, $\mathrm{Fe}_{3} \mathrm{O}_{4}, 100{ }^{\circ} \mathrm{C}, 16 \mathrm{~h}$, pH 6, 25 bar $\mathrm{H}_{2} / \mathrm{CO}_{2}$ (40:60); 0.17 mmol, $\mathrm{Fe}_{3} \mathrm{O}_{4}$, $100{ }^{\circ} \mathrm{C}, 16 \mathrm{~h}, \mathrm{pH} 9,25$ bar $\mathrm{H}_{2} / \mathrm{CO}_{2}(40: 60)$; 4) 0.17 mmol, $\mathrm{Fe}_{3} \mathrm{O}_{4}$, $100{ }^{\circ} \mathrm{C}, 16 \mathrm{~h}, \mathrm{pH} 9,25$ bar $\left.\mathrm{H}_{2} / \mathrm{CO}_{2}(40: 60) ; 5\right) 0.13$ mmol, $\mathrm{Ni}_{3} \mathrm{Fe}, 100$ ${ }^{\circ} \mathrm{C}, 16 \mathrm{~h}, \mathrm{pH} 5,25$ bar $\mathrm{H}_{2} / \mathrm{CO}_{2}(40: 60)$; 6) $0.13 \mathrm{mmol}, \mathrm{Ni}_{3} \mathrm{Fe}, 100{ }^{\circ} \mathrm{C}$, $16 \mathrm{~h}, \mathrm{pH} 7-8,25$ bar $\mathrm{H}_{2} / \mathrm{CO}_{2}$ (40:60). Columns 1, 3, 5: $\mathrm{pH}<7$; Columns 2, 4, 6: $\mathrm{pH}>8$. 
Using greigite, magnetite or awaruite as catalysts, the synthesis of formate, acetate, methanol and pyruvate from $\mathrm{H}_{2}$ and $\mathrm{CO}_{2}$ under hydrothermal conditions is facile. The synthesis of formate and acetate is furthermore robust to the catalyst employed. The main product we observed is formate (Fig. 2), which is also the main organic product found in alkaline hydrothermal vent effluent ${ }^{19}$. A possible mechanism for the formation of formate is given in Figs. S18 and S19. The reaction products we observe very closely resemble those of the acetyl-CoA pathway to pyruvate ${ }^{4}$ (Fig. 3), which, in both the bacterial and archaeal version ${ }^{4,7}$, entails eleven main enzymes totalling $\sim 15,000$ amino acid residues ${ }^{6}$ plus six organic cofactors each with complex biosynthetic routes ${ }^{7}$. The bacterial and archaeal versions of the pathway involve evolutionarily unrelated enzymes but chemically similar methyl synthesis routes ${ }^{4,7}$. The reaction steps of the acetyl-CoA pathway employed by modern metabolism are shown in Fig. 3. The biological pathway involves the stepwise conservation of chemical energy during $\mathrm{CO}_{2}$ fixation as acetyl-nickel, acetyl-thioester, acetyl-phosphate, and ATP via substrate level phosphorylation (marked with an asterisk in Fig. 3).

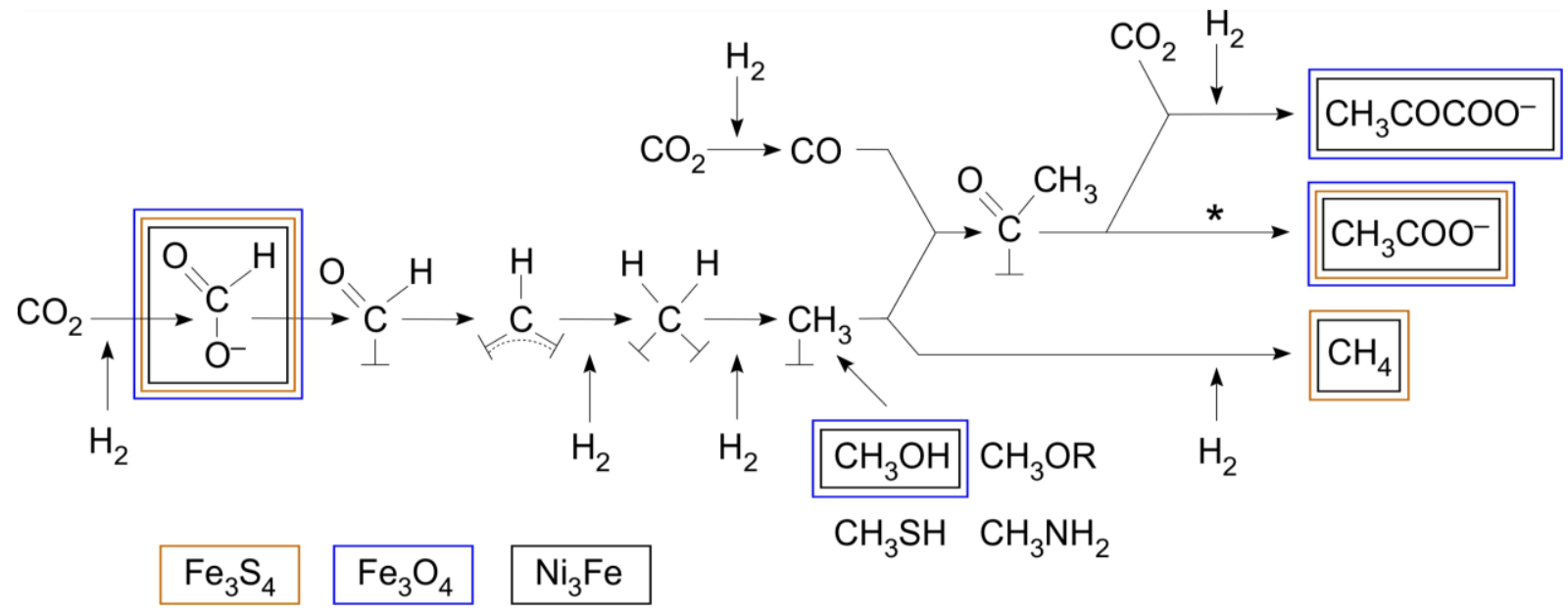

Figure 3: Congruence between the acetyl-CoA pathway and reactions catalysed by three iron minerals formed in hydrothermal vents. The chemical reactions summarize the acetyl-CoA pathway as it occurs in hydrogenotrophic bacteria and in archaea as depicted in ref. 4, with the exception of free formate later discovered in the archaeal pathway ${ }^{26}$. The methenyl $(=\mathrm{CH}-)$, methylene $\left(-\mathrm{CH}_{2}-\right)$, and methyl $\left(-\mathrm{CH}_{3}\right)$ groups of the bacterial and archaeal pathway are bound to tetrahydrofolate and tetrahydromethanopterin, respectively, generically indicated as catalysts $(\perp)$ here. Coloured boxes indicate products observed in reactions using 


\begin{abstract}
iron mineral catalysts. An asterisk indicates the reaction sequence in which energy is conserved as ATP via substrate level phosphorylation in the biological pathway (the acyl-nickel, thioester and acyl-phosphate intermediates that the enzymatic pathway employs for the stepwise conservation of free energy in the exergonic conversion of the nickelbound acyl group to $\mathrm{ATP}^{4}$ are not shown). All products shown were observed at temperatures $\leq 100{ }^{\circ} \mathrm{C}$ and obtained within $<24 \mathrm{~h}$, except methane in the case of greigite, which was observed over the course of $24 \mathrm{~d}$ (Supplementary Fig. S8a). Methanol, methyl sulfide, methyl amines, and methoxy groups can serve as methyl donors for the pathway $^{4,27}$.
\end{abstract}

Proposals for the nature of primordial $\mathrm{CO}_{2}$ fixation and energy conservation at biochemical origins typically posit the participation of external energy sources ${ }^{28}$ such as UV light $^{29}$, heat, impact, pressure, electrical currents, or ion gradients ${ }^{20}$ to push organic synthesis forward. The reactions reported here require no additional energy source for a protometabolic acetyl-CoA pathway to unfold from $\mathrm{H}_{2}$ and $\mathrm{CO}_{2}$ other than the natural reactivity of two gasses and metal catalysts, indicating that membranes, though essential for the emergence of free-living cells ${ }^{17}$, were not required for primordial $\mathrm{CO}_{2}$ fixation along an exergonic, $\mathrm{H}_{2}$ dependent, nonenzymatic pathway to $\mathrm{C} 3$ products. The energy for the synthesis of compounds capable of phosphorylating ADP via substrate level phosphorylation ${ }^{4,5,17}$ - for reactions reported here, and for those of the enzymatically catalysed acetyl-CoA pathway, stems from the exergonic synthesis of biologically relevant organic compounds from $\mathrm{H}_{2}$ and $\mathrm{CO}_{2}$. Our findings suggest that abiotic, geochemical versions of the energy releasing reactions underlying the acetyl-CoA pathway very likely preceded the enzymes that catalyse it today ${ }^{4,7,13,30}$. The simplicity and primordial nature of these reactions furthermore suggest that metabolism could initiate by a similar route elsewhere, independent of light.

\title{
Contributions
}

W.F.M., H.T., J.M. and M.P. designed the awaruite experiments, M.P. performed the awaruite experiments and assembled the results for the main text and SI material. K.B.M. designed and performed the magnetite experiments, S.J.V. performed exploratory experiments with 
magnetite. Design of the greigite experiments was done by K.I. and Y.K., K.I. performed the experiments. H.T. and M.Y. designed and synthesized the awaruite nanoparticles and performed XRD and TEM measurements for magnetite and awaruite experiments. M.K.N. performed and interpreted the thermodynamics calculations. K.K. and M.P. formulated the $\mathrm{H}_{2}$ reduction mechanism. W.F.M. wrote the initial draft of the main text and all authors edited the manuscript.

\section{Acknowledgements}

We thank Yitao Dai for setting up gas analysis for the awaruite experiments, Alexander Bähr, Andrey do Nascima Vieira and Perlina Lim for scientific support and Joana C. Xavier for discussions. For funding, W.F.M. and H.T. thank the Deutsche Forschungsgemeinschaft (MA-1426/21-1 / TU 315/8-1), W.F.M thanks the European Research Council (ERC 666053) and the VW foundation (93 046). This work is partly supported by IMPRS-RECHARGE and MAXNET Energy consortium of the Max Planck Society. K.I. and Y.K. thank JSPS KAKENHI Grant-in-Aid for Scientific Research on Innovative Areas (K.I.: JP17H05240 / Y.K.: 26106004). K.I. is also supported by Grant-in-Aid for Young Scientists B (JP17K15255). J.M. thanks the European Research Council (ERC 639170) and ANR LabEX (ANR-10-LABX-0026 CSC).

\section{References}

1. Baross, J. A. \& Hoffman, S. E. Submarine hydrothermal vents and associated gradient environments as sites for the origin and evolution of life. Orig. Life Evol. Biosph. 15, 327-345 (1985).

2. Sleep, N. H., Bird, D. K. \& Pope, E. C. Serpentinite and the dawn of life. Philos. Trans. R. Soc. B Biol. Sci. 366, 2857-2869 (2011).

3. Arndt, N. T. \& Nisbet, E. G. Processes on the young Earth and the habitats of early life. Annu. Rev. Earth Planet. Sci. 40, 521-549 (2012).

4. Fuchs, G. Alternative pathways of carbon dioxide fixation: Insights into the early evolution of life? Annu. Rev. Microbiol. 65, 631-658 (2011).

5. Müller, V., Chowdhury, N. P. \& Basen, M. Electron bifurcation: A long-hidden energy-coupling mechanism. Annu. Rev. Microbiol. 72, 331-353 (2018).

6. Ragsdale, S. W. \& Pierce, E. Acetogenesis and the Wood-Ljungdahl pathway of $\mathrm{CO}_{2}$ 
fixation. Biochim. Biophys. Acta 1784, 1873-1898 (2008).

7. Sousa, F. L. \& Martin, W. F. Biochemical fossils of the ancient transition from geoenergetics to bioenergetics in prokaryotic one carbon compound metabolism. Biochim. Biophys. Acta - Bioenerg. 1837, 964-981 (2014).

8. Weiss, M. C. et al. The physiology and habitat of the last universal common ancestor. Nat. Microbiol. 1, 16116 (2016).

9. McCollom, T. M. Abiotic methane formation during experimental serpentinization of olivine. Proc. Natl. Acad. Sci. U. S. A. 113, 13965-13970 (2016).

10. McDermott, J. M., Seewald, J. S., German, C. R. \& Sylva, S. P. Pathways for abiotic organic synthesis at submarine hydrothermal fields. Proc. Natl. Acad. Sci. U. S. A. 112, 7668-7672 (2015).

11. Huber, C. \& Wächtershäuser, G. Activated acetic acid by carbon fixation on (Fe,Ni)S under primordial conditions. Science 276, 245-248 (1997).

12. He, C., Tian, G., Liu, Z. \& Feng, S. A mild hydrothermal route to fix carbon dioxide to simple carboxylic acids. Org. Lett. 12, 649-651 (2010).

13. Varma, S. J., Muchowska, K. B., Chatelain, P. \& Moran, J. Native iron reduces $\mathrm{CO}_{2}$ to intermediates and endproducts of the acetyl-CoA pathway. Nat. Ecol. Evol. 2, 10191024 (2018).

14. Roldan, A. et al. Bio-inspired $\mathrm{CO}_{2}$ conversion by iron sulfide catalysts under sustainable conditions. Chem. Commun. 51, 7501-7504 (2015).

15. Ménez, B. et al. Abiotic synthesis of amino acids in the recesses of the oceanic lithosphere. Nature 564, 59-63 (2018).

16. Klein, F. \& Bach, W. Fe-Ni-Co-O-S phase relations in peridotite-seawater interactions. J. Petrol. 50, 37-59 (2009).

17. Martin, W. \& Russell, M. J. On the origin of biochemistry at an alkaline hydrothermal vent. Philos. Trans. R. Soc. B Biol. Sci. 362, 1887-1925 (2007).

18. Preiner, M. et al. Serpentinization: Connecting geochemistry, ancient metabolism and industrial hydrogenation. Life 8, 41 (2018).

19. Schrenk, M. O., Brazelton, W. J. \& Lang, S. Q. Serpentinization, carbon, and deep life. Rev. Mineral. Geochemistry 75, 575-606 (2013).

20. White, L. M., Bhartia, R., Stucky, G. D., Kanik, I. \& Russell, M. J. Mackinawite and greigite in ancient alkaline hydrothermal chimneys: Identifying potential key catalysts for emergent life. Earth Planet. Sci. Lett. 430, 105-114 (2015).

21. Dayhoff, M. O. \& Eck, R. V. Evolution of the structure of ferredoxin based on 
surviving relics of primitive amino acid sequences. Science 152, 363-366 (1966).

22. McCollom, T. M. \& Seewald, J. S. Serpentinites, hydrogen, and life. Elements 9, 129134 (2013).

23. Kelley, D. S. et al. An off-axis hydrothermal vent field near the Mid-Atlantic Ridge at 30 degrees N. Nature 412, 145-149 (2001).

24. Horita, J. \& Berndt, M. E. Abiogenic methane formation and isotopic fractionation under hydrothermal conditions. Sci. Rep. 285, 1055-1057 (1999).

25. Buckel, W. \& Thauer, R. K. Flavin-based electron bifurcation, ferredoxin, flavodoxin, and anaerobic respiration with protons $(\mathrm{Ech})$ or $\mathrm{NAD}^{+}(\mathrm{Rnf})$ as electron acceptors: $\mathrm{A}$ historical review. Front. Microbiol. 9, (2018).

26. Wagner, T., Ermler, U. \& Shima, S. The methanogenic $\mathrm{CO}_{2}$ reducing-and-fixing enzyme is bifunctional and contains 46 [4Fe-4S] clusters. Science 354, 114-117 (2015).

27. Mayumi, D. et al. Methane production from coal by a single methanogen. Science 354, 222-226 (2016).

28. Kaufmann, M. On the free energy that drove primordial anabolism. Int. J. Mol. Sci. 10, 1853-1871 (2009).

29. Patel, B. H., Percivalle, C., Ritson, D. J., Duffy, C. D. \& Sutherland, J. D. Common origins of RNA, protein and lipid precursors in a cyanosulfidic protometabolism. Nat. Chem. 7, 301-307 (2015).

30. Muchowska, K. B. et al. Metals promote sequences of the reverse Krebs cycle. Nat. Ecol. Evol. 1, 1716-1721 (2017).

\section{Methods}

General information. An overview of the performed experiments can be found in Fig. S1, and relevant controls - in Figs. S3-S6. The quantity of each transition metal reagent tested as carbon fixation catalyst was normalised to contain the same number of mmol of metal atoms across the experiments. For example, " $1 \mathrm{mmol}$ metal atoms" corresponds to: $0.33 \mathrm{mmol}$ greigite $\mathrm{Fe}_{3} \mathrm{~S}_{4}(99 \mathrm{mg}), 0.33 \mathrm{mmol}$ magnetite $\mathrm{Fe}_{3} \mathrm{O}_{4}(77 \mathrm{mg})$, and $0.25 \mathrm{mmol}$ awaruite $\mathrm{Ni}_{3} \mathrm{Fe}$ $(58 \mathrm{mg})$. Each reaction was performed in at least triplicate. Information on suppliers, grade and purity of all used reagents are listed in the Supplementary Information. 
Synthesis of greigite $\left(\mathrm{Fe}_{3} \mathrm{~S}_{4}\right)$. Every piece of apparatus used in greigite synthesis was stored in an anaerobic chamber (Coy Laboratory Products) under a gas mixture of $\mathrm{N}_{2} / \mathrm{H}_{2} / \mathrm{CO}_{2}$ (80:5:15) for at least $48 \mathrm{~h}$ before use, to remove the residual oxygen. Reagents for greigite synthesis were purged with $\mathrm{N}_{2}$ before use unless otherwise stated. Amorphous $\mathrm{FeO}(\mathrm{OH})$ was synthesized as reported previously ${ }^{31}$ and suspended in Milli-Q water $(0.30 \mathrm{~mol} / \mathrm{L})$ under air atmosphere. After purging with $\mathrm{N}_{2}$, this suspension was stored in a glass bottle under $\mathrm{N}_{2} / \mathrm{H}_{2} / \mathrm{CO}_{2}(80: 5: 15)$. The solutions of $\mathrm{Na}_{2} \mathrm{~S}(1.0 \mathrm{M})$ and $\mathrm{H}_{2} \mathrm{SO}_{4}(2.0 \mathrm{M})$ were prepared as reported previously ${ }^{32}$ and stored in a glass bottle under $\mathrm{N}_{2}$. Greigite was synthesised in a solid-gas reaction system as reported previously ${ }^{32}$ with slight modifications. In brief, amorphous $\mathrm{FeO}(\mathrm{OH})(0.66 \mathrm{mmol}, 2.2 \mathrm{~mL}$ of water suspension) was aliquoted to a glass reaction vessel, and a test tube containing $1.0 \mathrm{~mL}$ of the $\mathrm{Na}_{2} \mathrm{~S}$ solution was placed in the vessel inside the anaerobic chamber. The vessel was sealed with an ETFE-coated butyl rubber stopper and an aluminium seal. Then, the vessel was removed from the anaerobic chamber and the headspace gas was replaced with Ar. After returning the vessel into the anaerobic chamber, $\mathrm{H}_{2} \mathrm{~S}$ gas was generated inside the vessel by injecting $0.5 \mathrm{~mL}$ of the $\mathrm{H}_{2} \mathrm{SO}_{4}$ solution to the $\mathrm{Na}_{2} \mathrm{~S}$ solution in the test tube using a disposable Myjector syringe (Terumo). The vessel was incubated at $80{ }^{\circ} \mathrm{C}$ for 3 hours. The resulting greigite suspension was collected by pipetting from several reaction vessels, washed with $0.5 \mathrm{M} \mathrm{HCl}$ and then rinsed with $\mathrm{N}_{2}$ purged Milli-Q water in the anaerobic chamber as described previously ${ }^{32}$.

$\mathrm{CO}_{2}$ fixation catalysed by greigite. Synthesised greigite $(0.33 \mathrm{mmol})$ was resuspended in 3 $\mathrm{mL}$ of potassium phosphate buffer $(20 \mathrm{mM})$ of a designated $\mathrm{pH}$. The greigite suspension was placed in a fresh glass reaction vessel, which was then sealed with an ETFE-coated butyl rubber stopper and an aluminium seal. The vessel was then removed from the chamber, and the headspace gas was replaced with $\mathrm{H}_{2} / \mathrm{CO}_{2}(80: 20)$ or $\mathrm{CO}_{2}$ outside the chamber. The vessels were incubated at $100{ }^{\circ} \mathrm{C}$ over 4 to $24 \mathrm{~h}$.

HPLC analysis (greigite experiments). Liquid phase components were analysed on a D-2000 LaChrom Elite HPLC system (Hitachi), equipped with Aminex ${ }^{\circledR}$ HPX-87H column (300 mm, $7.8 \mathrm{~mm}$ I.D.; Bio-Rad Laboratories) and an L-2400 UV detector at $240 \mathrm{~nm}$ and L-2490 RI detector as described previously ${ }^{33}$. Supernatants obtained in the $\mathrm{CO}_{2}$ reduction experiments were collected after centrifugation inside the anaerobic chamber. $10 \mu \mathrm{L}$ of the obtained supernatants were directly injected into the HPLC circuit and chromatographed under an isocratic flow of $0.7 \mathrm{~mL} / \mathrm{min}$ (Eluting buffer: $10 \mathrm{mM} \mathrm{H}_{2} \mathrm{SO}_{4}$ in $\mathrm{H}_{2} \mathrm{O}$ ). The column temperature was maintained at $50{ }^{\circ} \mathrm{C}$. Identities of the detected analytes were determined by 
the LC-MS system: Agilent 1200 HPLC (Agilent Technologies) coupled to an HCT Ultra mass spectrometer (Bruker Daltonics), using a Shodex ${ }^{\circledR}$ HILICpak VG-50 2D column (150 mm, 2 mm I.D.; Showa denko). The supernatant prepared as above was mixed with an equal amount of acetonitrile. Then, $5 \mu \mathrm{L}$ of the mixture was injected into the HPLC circuit and chromatographed under an isocratic flow of $0.1 \mathrm{~mL} / \mathrm{min}$ (Eluting solution: a mixture of acetonitrile and $0.25 \%$ ammonia water with 80:20 ratio). Column temperature was maintained at $30{ }^{\circ} \mathrm{C}$.

Synthesis of awaruite ( $\mathrm{Ni}_{3} \mathrm{Fe}$ ) nanoparticles. As previously reported ${ }^{34}$, spent tea leaves can be used as sustainable hard template to synthesise native metal nanoparticles in the desired composition. For the synthesis of nanoparticular $\mathrm{Ni}_{3} \mathrm{Fe}$, washed and dried tea leaves were added into an aqueous solution of $\mathrm{Ni}\left(\mathrm{NO}_{3}\right)_{2} \cdot 6 \mathrm{H}_{2} \mathrm{O}$ and $\mathrm{Fe}\left(\mathrm{NO}_{3}\right)_{2} \cdot 9 \mathrm{H}_{2} \mathrm{O}$ (molar ratio of 3:1) and stirred at room temperature for $2 \mathrm{~h}$. The mass ratio of tea leaves and metal precursors was set at 2:1. Due to the low decomposition temperature of the metal nitrate salt (below $200^{\circ} \mathrm{C}$ ), metal oxide nanoparticles can be formed in the pore confinement of the template before its structural damage/decomposition. The carbon-based tea leaf template was burned out in air atmosphere (at $550{ }^{\circ} \mathrm{C}$ for $4 \mathrm{~h}$ ) and the resulting $\mathrm{Ni}_{3} \mathrm{Fe}$ oxide was washed with $0.1 \mathrm{M} \mathrm{HCl}$ solution for $2 \mathrm{~h}$ and cleaned with deionized water. Finally, the product was treated in a reductive $10 \% \mathrm{H}_{2} / \operatorname{argon}$ flow $(100 \mathrm{~mL} / \mathrm{min})$ at $500{ }^{\circ} \mathrm{C}$ for $2 \mathrm{~h}$ to generate the intermetallic $\mathrm{Ni}_{3} \mathrm{Fe}$ compound ${ }^{34,35}$.

$\mathrm{CO}_{2}$ fixation catalysed by magnetite $\left(\mathrm{Fe}_{3} \mathrm{O}_{4}\right)$ and awaruite $\left(\mathrm{Ni}_{3} \mathrm{Fe}\right)$. Awaruite and magnetite powder (commercial) were placed in a $1.5 \mathrm{~mL}$ glass vial. In the case of magnetite experiments, a clean PTFE-coated stir bar was added to the vial. Then, the reaction vials were filled with $1.0 \mathrm{~mL}$ of Milli-Q water. Whenever the effect of an increased $\mathrm{pH}$ of the reaction mixtures was tested, solid $\mathrm{KOH}$ was added into the Milli-Q water before the reaction (45 $\mathrm{mg} / \mathrm{mL}$ ). $\mathrm{KOH}$ had been tested for contaminants via the ${ }^{1} \mathrm{H}-\mathrm{NMR}$ analysis (Supplementary Fig. S16) To prevent cross-contamination while allowing for the gas to easily reach the reaction mixture, the vials were closed with caps with punctured PTFE septa. The reaction vials (3-12) were placed in a stainless-steel pressure reactor (Berghof or Parr) which was then sealed, flushed three times with ca. 5 bar $\mathrm{CO}_{2}$, pressurized to a final value of 25 bar $\mathrm{CO}_{2}$ (unless noted otherwise), and heated at the desired temperature (an external heating mantle was used) for $16 \mathrm{~h}$. At a reaction temperature of $100{ }^{\circ} \mathrm{C}$, a maximum pressure of ca. $30 \mathrm{bar}$ was reached. After the reaction, the reactor was allowed to cool down to room temperature (3-4 h from $100{ }^{\circ} \mathrm{C}, 2-3$ hfrom $70{ }^{\circ} \mathrm{C}$ ) before sample analysis ${ }^{13,30}$. 
Experiments with iron powder or hydrogen gas. The experiments were performed according to the general procedure described above, except that $10 \mathrm{mmol}(560 \mathrm{mg}) \mathrm{Fe}^{0}$ powder was first placed in the reaction vials, followed by the mineral tested. Further experiments exploring the impact of the amount of $\mathrm{Fe}^{0}$ powder are displayed in the supplementary material (Fig. S12).

Whenever $\mathrm{H}_{2}$ was used in the experiments, the pressure reactor was first flushed with $\mathrm{CO}_{2}$, then pressurized with 10 bar of $\mathrm{H}_{2}$ and then brought to 25 bar by adding $\mathrm{CO}_{2}$ again $\left(\mathrm{H}_{2} / \mathrm{CO}_{2}\right.$ approximately 40:60).

Work-up procedure for reaction mixtures $\left(\mathrm{Ni}_{3} \mathrm{Fe}\right.$ and $\left.\mathrm{Fe}_{3} \mathrm{O}_{4}\right)$. The $\mathrm{pH}$ of individual reaction mixtures was determined via TRITEST L pH 1-11 pH papers (Macherey-Nagel) directly after the reaction. The $\mathrm{CO}_{2}$ dissolved in the reaction mixture during the reaction decreased the reaction $\mathrm{pH}$ values due to the formation of carbonic acid. Reaction mixtures that did not contain $\mathrm{KOH}$ were either treated with ca. $45 \mathrm{mg}$ solid $\mathrm{KOH}$ per $1 \mathrm{~mL}$ reaction mixture to precipitate the metal ions as hydroxides (in the case of $\mathrm{Fe}_{3} \mathrm{O}_{4}$ ), or left untreated (in the case of $\mathrm{Ni}_{3} \mathrm{Fe}$ ). All samples were then centrifuged at $13.000 \mathrm{rpm}$ for $10 \mathrm{~min}$. The supernatant was then separated from the precipitate (catalyst) and stored at $4{ }^{\circ} \mathrm{C}$ overnight or longer until the NMR or HPLC analysis.

NMR analysis (for awaruite and magnetite experiments). Concentrations of formate, acetate, pyruvate and methanol (as methoxide) were determined by ${ }^{1} \mathrm{H}-\mathrm{NMR}$, following the protocol established in Varma et $\mathrm{al}^{13}$. The supernatant of the centrifuged samples was therefore mixed with sodium 3-(trimethylsilyl)-1-propanesulfonate (DSS) $\mathrm{D}_{2} \mathrm{O}$ - solution as the internal standard ( $\mathrm{CH}_{3}$ peak at $\left.0 \mathrm{ppm}\right)$. NMR spectra were acquired on a Bruker Avance III -600 or a Bruker Avance 300 spectrometer at 297 K, using a ZGESGP pulse program. 32 scans were acquired for each sample, the relaxation delay was set to $40 \mathrm{~s}(600 \mathrm{MHz})$ and $87 \mathrm{~s}(300 \mathrm{MHz})$, with a spectral width of $12315 \mathrm{ppm}(600 \mathrm{MHz})$ or $11963 \mathrm{ppm}(300 \mathrm{MHz})$. Analysis and integration were performed using MestReNova (10.0.2) software. Shifts of the measured products are depicted in Fig. S17.

Powder X-ray diffraction (XRD). XRD analysis was performed for pre- and post-reaction catalysts. For greigite, XRD specimen was prepared as described previously ${ }^{32}$. In brief, the sample was collected by centrifugation, and the obtained pellet was directly mounted as a slurry form on a silicon holder (SanyuShoko), and then sealed by using polyimide film (Nilaco Corporation) and vacuum grease (JEOL) to avoid possible desiccation and oxidation during the analysis. The specimen was analysed using a RINT2000 X-ray diffractometer (Rigaku) at room temperature for $\mathrm{CuK} \alpha_{1,2}$ radiation scanning at a step interval of $0.02^{\circ} 2 \theta$ 
and a counting time of 2 seconds with a $2 \theta$ range from $20^{\circ}$ to $60^{\circ}$, operating at an accelerating voltage of $40 \mathrm{kV}$ at $30 \mathrm{~mA}$. In order to prepare specimens for magnetite and awaruite experiments, the samples were collected, washed with Milli-Q water and dried under vacuum. XRD patterns of these specimens were collected at room temperature by using a theta-theta diffractometer (Stoe) in Bragg-Brentano geometry for $\mathrm{CuK} \alpha_{1,2}$ radiation scanning at a step interval of $0.04^{\circ} 2 \theta$ and a counting time of 6 seconds with a $2 \theta$ range from $20^{\circ}$ to $60^{\circ}$.

Electron microscopy. Electron microscopic observation was conducted for pre-reaction catalysts to check their morphology. For greigite, a specimen for scanning electron microscopy was prepared as described previously ${ }^{32}$. Briefly, in the anaerobic chamber, greigite was rinsed at least three times with $\mathrm{N}_{2}$-purged Milli-Q water, dried at room temperature, and then mounted on an aluminium stab using carbon tape. The specimen was taken out from the anaerobic chamber, coated with platinum/palladium alloy with an ion sputter E102 (Hitachi) and observed on a JSM-6330F (JEOL) or JSM-7800F (JEOL) fieldemission scanning electron microscope (FE-SEM) at an acceleration voltage of $5 \mathrm{kV}$. For magnetite and awaruite, specimens for transmission electron microscopy were prepared. The samples were collected and embedded in Spurr resin (hard mixture). Obtained resin blocks were trimmed using an EM TRIM milling system (Leica). Thin sections were cut from the resin blocks by using a microtome with a $35^{\circ}$ diamond knife (Reichert Ultra-Cut), dispersed in Milli-Q water and transferred from the water surface on lacey carbon film-coated $\mathrm{Cu}$ grids (400 mesh), and observed on an S-5500 (Hitachi) transmission electron microscope at an acceleration voltage of $30 \mathrm{kV}$. Elemental mapping was conducted on the specimens prepared as above by using energy dispersive X-ray spectrometry (EDS) with a $\mathrm{Si}$ (Li) detector and ultrathin polymer window, operated at an acceleration voltage of $30 \mathrm{kV}$ (Fig. S2).

Thermodynamic calculations. For Gibbs free energy yield $(\Delta \mathrm{G})$ calculations, published values of $\Delta H$ and $\Delta \mathrm{G}$ values were used ${ }^{36,37}$. The effect of temperature on the Gibbs free energy yield was calculated using the Gibbs-Helmholz equation. Equilibrium constants at different temperatures were adjusted using the van't Hoff equation (detailed equations in supplementary information). Corrections based on non-standard pressures were estimated using partial molar volume changes of the reactions ${ }^{38}$. For any organic compounds that were not detected, an aqueous concentration of $0.1 \mu \mathrm{M}$ was assumed. For $\mathrm{CH}_{4}$, a partial pressure of $10^{-7} \mathrm{~atm}$ was assumed when not detected. In reactions containing $\mathrm{Fe}^{0}$ as an electron donor (Tab. S2), the $\mathrm{H}_{2}$ concentration was estimated by assuming $\mathrm{H}_{2}$-dependent $\mathrm{CO}_{2}$ reduction to 
formate reached equilibrium. Final $\mathrm{H}_{2}$ and $\mathrm{CO}_{2}$ concentrations were estimated based on the measured products (subtracting $1 \mathrm{~mol} \mathrm{H}_{2}$ per mole formate detected).

\section{References:}

31. Lovley, D. R. \& Phillips, E. J. Organic matter mineralization with reduction of ferric iron in anaerobic sediments. Appl. Environ. Microbiol. 51, 683-689 (1986).

32. Igarashi, K., Yamamura, Y. \& Kuwabara, T. Natural synthesis of bioactive greigite by solid - gas reactions. Geochim. Cosmochim. Acta 191, 47-57 (2016).

33. Kato, S., Yumoto, I. \& Kamagata, Y. Isolation of acetogenic bacteria that induce biocorrosion by utilizing metallic iron as the sole electron donor. Appl. Environ. Microbiol. 81, 67-73 (2015).

34. Deng, X., Chan, C. K. \& Tüysüz, H. Spent tea leaf templating of cobalt-based mixed oxide nanocrystals for water oxidation. ACS Appl. Mater. Interfaces 8, 32488-32495 (2016).

35. Yu, M., Moon, G., Bill, E. \& Tüysüz, H. Optimizing Ni-Fe oxide electrocatalysts for oxygen evolution reaction by using hard templating as a toolbox. Appl. Energy Mater. 2, 1199-1209 (2019).

36. Hanselmann, K. W. Microbial energetics applied to waste repositories. Experientia 47, 645-687 (1991).

37. Amend, J. P. \& Shock, E. L. Energetics of overall metabolic reactions of thermophilic and hyperthermophilic archaea and bacteria. FEMS Microbiol. Rev. 25, 175-243 (2001).

38. Wang, G., Spivack, A. J. \& Hondt, S. D. Gibbs energies of reaction and microbial mutualism in anaerobic deep subseafloor sediments of ODP Site 1226. Geochim. Cosmochim. Acta 74, 3938-3947 (2010). 